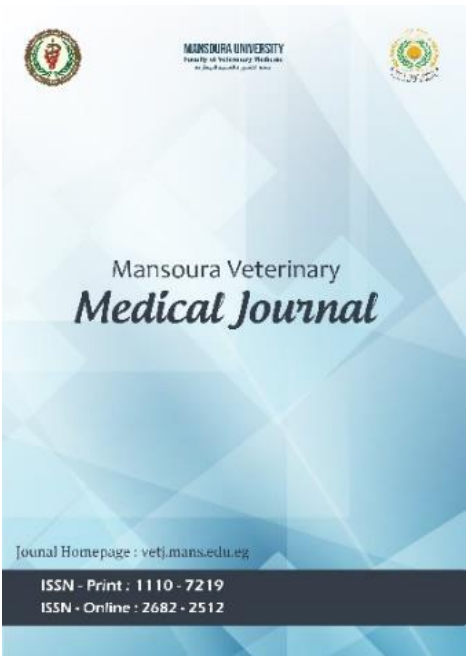

\title{
Impact of crossbreeding on performance traits in two breeds of rabbit under Egyptian conditions
}

Shimaa Sakr, Hend Radwan, Adel El-Desoky, Ragab Darwish, Mohamed Fouda

To cite this article: Shimaa Sakr, Hend Radwan, Adel El-Desoky, Ragab Darwish, Mohamed Fouda. Impact of crossbreeding on performance traits in two breeds of rabbit under Egyptian conditions. Mansoura Veterinary Medical Journal 2020; 21, 2: 19-24.

To link to this article: https://doi.org/10.35943/mvmj.2020.21.2.0206

Published online: 25 June 2020

Submit your article to this journal

(D) 


\title{
Impact of crossbreeding on performance traits in two breeds of rabbit under Egyptian conditions
}

\author{
Shimaa Sakr ${ }^{*}$, Hend Radwan ${ }^{1}$, Adel El-Desoky ${ }^{2}$, Ragab Darwish ${ }^{1}$, Mohamed Fouda ${ }^{1}$ \\ ${ }^{1}$ Department of Husbandry and Development of Animal Wealth, Faculty of Veterinary Medicine, Mansoura University, Mansoura 35516, Egypt \\ ${ }^{2}$ Department of Waterfowls and Rabbits Researches, Animal Production Research Institute, Dokki, Giza, Egypt
}

\section{ARTICLE HISTORY}

Received: 09.02.2020

Revised: 14.03 .2020

Accepted: 23.03 .2020

Address correspondence to Shimaa A.Sakr; Tel: +201067813499; E-mail: shimaaheshamgr@yahoo.com

\section{ABSTRACT}

\begin{abstract}
Objective: The objectives of this study were to investigate the effect of breed (V-Line and Baladi Black) on doe reproductive traits and their crossbreeding on litter traits and economic efficiency.

Design: Randomized controlled experimental study.

Procedures: A total of twenty adult females and six males from each breed with 2.75$3.00 \mathrm{~kg}$ of live body weight and 5-6 months of age were used. Experimental animals were divided into four groups (ten females and three males per each treatment). The first treatment was specified to $\mathrm{V}$-Line males with $\mathrm{V}$-Line females $(\mathrm{V} \times \mathrm{V})$, the second treatment contained Baladi Black males with V-Line females $(B \times V)$, the third treatment had the $V$ Line males with Baladi Black females $(\mathrm{V} \times \mathrm{B})$ and the fourth treatment contained the Baladi Black males with Baladi Black females $(B \times B)$. Within 12 hours after kindling, litters were checked and date of birth and number and weight of kits were recorded. The female was re-mated after 10 days from kindling. Young rabbits were weaned at five weeks of age and were transferred to the progeny cages with a group of five rabbits per cage. A total of 84 kids (twenty-one rabbits per genetic group) were fattened for about 9 weeks (from 5 th to 14 th weeks of age).

Results: The results showed that breed had no significant effect on all reproductive traits, litter size and pre-weaning mortality rate at three stages of age (at birth, 21 day and 35 day). There were however, highly significant differences for litter weight and mean bunny weight at the same stages of age. Also, significant differences were detected for weight gain and average daily gain where the litter of Vơ $\times \mathrm{V}$ g genetic group outperformed other genetic groups. Significant differences among genetic groups were detected for economic measures; litter of $\mathbf{V o}^{2} \times \mathrm{V}$ ? genetic group recorded the highest values for total returns, net return and economic efficiency.

Conclusion and clinical relevance: It could be concluded that purebred $V$ Line $\left(V^{2} \times V \%\right)$ showed improvement in the litter traits and economic efficiency compared with the other genetic groups.
\end{abstract}

Keywords: Crossbreeding, V-line, Baladi Black, performance trait

\section{INTRODUCTION}

Rabbit is a small livestock species has several characteristics as it needs less space and less feed because of small body size, short- generation interval, high prolificacy, potentials for genetic improvement, faster growth rate and high feed conversion efficiency. These are the attributes that make rabbits an ideal species for meat production compared to other species [1]. On top of that, rabbits are considered as one of numerous alternative species quite appropriate as a source of animal protei $n$ in the developing countries [2].

Rabbit's production directly relies on their reproductive performance. It therefore becomes an important hand in profit-making of commercial rabbit breeding. Many factors affect the reproductive performance such as age, weight at first service, longevity of the doe breed and season [3] combined with several traits which are considered as an indication of the mothering capability of the doe such as age at first service, kindling intervals, conception and kindling rates and litter size at birth and weaning [4].

Genetic diversity is enhanced among some local breeds (Baladi Red, Baladi White and Baladi Black) and different standard exotic breeds newly introduced to Egypt (New Zealand White and Californian) through crossbreeding experiments to improve doe reproductive performance, milk production, post-weaning growth, carcass and other traits [5]. Rabbit meat productivity is based on selection of pure breeds for meat traits and on their crosses [6].

Crossbreeding is one of the fast tools offered to breeders to improve many qualities and to esta blish gains in the performance in farm animals [7] and to increase production, produce superior crosses and to combine different characteristics in which the crossed breeds were premium through the explosion of heterosis [8]. 
Consequently, the objective of this study was to evaluate the effect of breed ( $V$-Line and Baladi Black) on doe reproductive traits and their cross breeding on litter traits and economic efficiency.

\section{MATERIAL AND METHODS}

\subsection{Experimental design}

The current study was conducted using V-Line and Baladi Black breeds at the rabbits' farm of El-Serw Animal Production Research Station, Animal Production Research Institute, Agricultural Research Center, Ministry of Agriculture, Egypt, during the period extended from November 2017 until March 2019. The total number of the animals used in the study was 52 rabbits. Twenty adult females and sixmales from each breed with 2.75-3.00 kg of live body weight and 5-6 months of age were used. Experimental animals were divided into four groups (ten females and three males per each treatment). The first trea tment was specified to $\mathrm{V}$-Line males with $\mathrm{V}$-Line females $(V \times V)$, the second treatment contained Baladi Black males with $\mathrm{V}$-Line females $(\mathrm{B} \times \mathrm{V})$, the third treatment had the $\mathrm{V}$ Line males with Baladi Black females $(V \times B)$ and the fourth treatment contained the Baladi Black males with Baladi Black females $(B \times B)$. Within 12 hours after kindling, litters were checked and da te of birth and number and weight of kits were recorded. The female was re-mated after 10 days from kindling. Young rabbits were weaned at five weeks of age and were transferred to the progeny cages with a group of five rabbits per cage. The resulting bunnies ( 84 kids) of the mating of four groups (twenty-one rabbits per each treatment) were used for fattening in the period from weaning (at 5 th week of a ge) up to marketing (at 14th week of age). Rabbits were housed separately in individual wirecages (50 L x $50 \mathrm{~W} \times 35 \mathrm{H} \mathrm{cm}$ ). Light was allowed 12-14 hour/day during the period of the study. Diets were offered ad libitum all over the experimental period in the form of pelleted rations, which was formulated in the farm from the available ingredients to cover the nutrient requirements of rabbits as recommended by [9] (Table 1 and 2). Environmental temperature was kept around 16-24 ㅇ․

\subsection{Studied traits}

\section{Reproductive traits (Rabbit's doe traits)}

Gestation length (GL), number of service per conception (NSC) which is the number of services required for the doe to be conceived, days open(DO) that is the period per days between kindling and conception and kindling interval (KI). II. Litters traits

Alive litter size (ALS): (at birth, at 21 day and 35 day of age), alive litter weight (ALW): (at birth, at 21 day and 35 day of age), average kit daily weight ga in: (birth-21 days, 2135 days and birth-weaning), average litter daily weight gain: (birth-21 days, 21-35 days and birth-weaning) and mortality rate (MR): (at birth, at 21 day and 35 day of age).

\section{Economic Efficiency}

Production cost based primarily on feeding cost together with mortality cost. Feeding cost repres ent about
$80 \%$ of total production cost in case of growing rabbits [10]. Since cost of feed may va rysignificantly from year to year, the cost a nalysis was carried out based on two levels of the a verage cost of feed and a verage price of rabbit at slaughter that considered as a revenue [11] .

Economic Efficiency (E.E) for meat production was calculated as follows:

1. Total feed intake $(\mathrm{Kg} /$ Rabbits $)=$ Daily feed intake $x 56$.

2. Total feed cost (L.E) $=$ Total feed intake $(\mathrm{Kg}) \times$ Price $/ \mathrm{kg}$ feed (L.E).

3. Total return/Rabbits (L.E) $=$ Total weight gain/ Rabbits (kg) $\times$ Price/kg live body weight (L.E).

4. Net return/ growing rabbits (L.E) = Total return/ growing rabbits (L.E) - Total feed cost/growing rabbits (L.E).

5. Economic efficiency (E.E) $=$ Net return/growing rabbits (L.E) / Total feed cost / growing rabbits (L.E).

\subsection{Data analysis}

Data were statistically analyzed using computer program of [12] using the general linear models (GLM). Significance among means was tested at $(P<0.05)$ using Duncan's New Multiple Rang Test [13] .

\section{RESULTS}

Data in Table 3 shows the reproductive performance of $\mathrm{V}$ Line and Baladi Blackrabbits which revealed non-significant $(P>0.05)$ differences between both breeds for all reproductive traits. Although, Baladi Black breed showed higher estimates for NSC, DO and KI but this did not reach to the level of significance and had lower GL compared wi th VLine breed.

Table 1. The composition and calculated chemical a nalysis of the diets fed to does rabbits.

\begin{tabular}{lc}
\hline Ingredients & Percent \\
Yellow corn & 12.50 \\
Barley & 10.00 \\
Wheat bran & 20.00 \\
Soybean meal (44\%) & 15.00 \\
Alfalfa hay & 35.00 \\
Mint straw & 5.000 \\
Di-calcium phosphate & 1.200 \\
Lime stone & 0.700 \\
Salt & 0.300 \\
Premix & 0.300 \\
Total & 100 \\
Calculated chemical analysis of diets & \\
Digestible energy (DE) (k cal / & 2755 \\
kg) & 18.25 \\
Crud Protein & 14.17 \\
Crud fiber & 2.680 \\
Ether extract & 1.121 \\
Calcium & 0.482 \\
Available phosphorus & 0.913 \\
Lysine & 0.323 \\
Methionine &
\end{tabular}


As for the effect of breed on litter size, the current study showed a non- significant effect to the breed at different stages of age (birth, 21d and weaning). V-Line breed has higher alive litter size at birth (ALSB), litter size at 21 day (LS21) and litter size at weaning (LSW) than Baladi Black breed. A significant difference $(P>0.0001)$ for alive litter weight and mean body weight at birth, 21day and weaning had been detected among genetic groups,

Table 1. The composition and calculated chemical a nalysis of the tested diets fed to growing rabbits.

\begin{tabular}{lc}
\multicolumn{1}{l}{ Ingredients } & Percent \\
& \\
Yellow corn & 15.00 \\
Barley & 12.50 \\
Wheat bran & 20.00 \\
Soybean meal (44\%) & 10.00 \\
Alfalfa hay & 35.00 \\
Mint straw & 5.000 \\
Di-calcium Phosphate & 1.200 \\
Lime stone & 0.700 \\
Salt & 0.300 \\
Premix & 0.300 \\
Total & 100 \\
Calculated chemical analysis of diets & \\
Digestible energy (DE) & \\
(k cal / kg) & 2773 \\
Crud Protein & 16.54 \\
Crud Fiber & 14.02 \\
Ether Extract & 2.760 \\
Calcium & 1.108 \\
Available Phosphorus & 0.475 \\
Lysine & 0.778 \\
Methionine & 0.298
\end{tabular}

\section{DISCUSSION}

The results were in an agreement with those of [14] who reported a non-significant effect of breed on most reproductive traits. There were no any significant differences in kindling interval and days open [15] and kindling interval and gestation length [16]. Moreover,[17] revealed non-significant differences among the genetic groups for gestation length and showed that gestation length considered a physiological state which is not dependent on breed and management but rather on the species. However, the slight variation in values might appeared as a result of breed differences, feeding regime and other management strategies involved as reported by [18]. In contrast, some investigations stated a significant effect of doe breed on kindling interval [19] and gestation length [20]. The superiority of $\mathrm{V}$-Line does for litter size could be explained in the light of the higher uterine capacity and the great ovulation rate [21]. The lack of significance in the current data of litter size is similar to these results obtained by [22] for litter size at wea ning, [19] and [20] for litter size at birth in New Zealand White (NZW) and Baladi Red rabbits, respectively. Also, the results are similar to those of [23] who reported a non-significant difference between Alex and purebred $\mathrm{V}$ Line $\left(\mathrm{V}^{2} \times \mathrm{V}\right.$ ) ) were the highest a mong the four genetic groups.

Regarding the effect of the breed on litter daily weight gain and kit daily weight gain, there were highly significant differences a mong the breeds within the periods from birth till 21day, 21 day till weaning (35day) and from 21 day till weaning. There were non-significant differences among genetic groups for litter mortality rate at different age interval (0-21, 21-35 and 0-35 d).

Data in Table 5 revealed a significant influence of breed on economic efficiency measures. $V$-Line breed recorded higher values for total returns (62.92 L.E), net return (35.90 L.E) and economic efficiency (1.39) than the other genetic groups.

Table 3. Reproductive performance of V-Line and Baladi Black breeds of rabbit.

\begin{tabular}{llrl} 
& \multicolumn{2}{c}{ Treatment groups } \\
\cline { 2 - 4 } $\begin{array}{l}\text { Reproductive } \\
\text { parameters }\end{array}$ & V-Line & Baladi Black & $\begin{array}{c}\text { P- } \\
\text { value }\end{array}$ \\
$\begin{array}{l}\text { Number of service } \\
\text { per conception } \\
\text { (NSC) }\end{array}$ & $2.23 \pm 0.14$ & $2.28 \pm 0.15$ & NS \\
$\begin{array}{l}\text { Gestation length } \\
\text { (GL) }\end{array}$ & $30.27 \pm 0.07$ & $30.02 \pm 0.07$ & NS \\
$\begin{array}{l}\text { Days open (DO) } \\
\text { Kindling interval } \\
\text { (KI) }\end{array}$ & $25.28 \pm 1.99$ & $27.55 \pm 2.03$ & NS \\
\hline
\end{tabular}

V-Line rabbits for litter size at 21 days. In contrast, the results of the current study contradict those of [19] who mentioned that NZW rabbits had a significantly $(P \leq 0.05)$ higher litter size at weaning than Baladi Red breed. [16] reported the same result for NZW breed as compared with California one. Furthermore, Ashour et al. [24] found significant differences $(P<0.05)$ among rabbit breeds (APRI and Baladi Black) for total litter size at birth, 21day and weaning and [17] as compared with Palomino brown and Havana Black for LSB and LSW.

The lack of significant effect of crossbreeding on litter size is similar to that obtained by [25] who found that dam and sire breed did not significantly $(P<0.05)$ influenced total number of litter born for Chinchilla breed and NZW rabbits. On contrary, [26] stated that purebred NZW exceeded significantly $(\mathrm{P} \leq 0.001)$ other crossbred Hyla rabbits (NZW $\times$ California) for litter size at birth and weaning. While, [27] concluded that crossbred litters showed higher LSB, LSW and mean kit weight at weaning than those of purebred litters.

In rabbits it has been shown that higher birth weights result in higher weaning weights which are affected by genotypeand environment especially feeding levels [28]. The maternal effect of the breed on litter weight and mean 
body weight is similar to that obtained by [20] who found that the White Giant rabbits recorded significantly $(P<0.01)$ higher estimates than did Soviet Chinchilla for both litter weight at birth and litter weight at weaning. [24] reported that both APRI and NZW rabbits recorded significantly $(P<0.05)$ higher values for both mean total litter weight at birth, mean weight of pups at birth, 21 days and weaning than Baladi Black.

Furthermore, [17] found that Havana black rabbits showed the highest significant value for litter weight at weaning than NZW, Palomino brown and California rabbit breed. In rabbits it has been shown that higher birth weights result in higher weaning weights which are affected by genotype and environment es pecially feeding levels [28]. Additionally, nutrition plays an important role in post weaning growth of rabbit pups [4].

The current results are in contrast with those obtained previously [19], who stated that the NZW was not significantly different for litter weight at birth and at weaning when compared to Baladi Red. Also, [16] mentioned the same result when compared NZW with Cal ifornia breed. Addi tionally, [24] reported non-significant differences among rabbit breeds (APRI, NZW and Baladi Black) for body weight at 21 days.

The significant influence of crossbreeding on litter weight is consistent with the findings of [26], who showed a significant effect $(P<0.05)$ for litter weight at different ages between crossbred Hyla rabbits and purebred NZW with favorable effect for purebred over crossbred one. While, [29] confirmed the same effect for body weight at weaning with favorable effect for crossbred (NZW X Dutch bel ted) than two purebreds (NZW and Dutch belted). Crossbred kits produced by mating does of exotic breeds with bucks of a local breed $\left(\mathrm{B}^{\sigma^{2}} \times \mathrm{V}^{\mathrm{P}}\right)$ were considerably heavier than those of the reciprocal cross without a significant effect. This phenomenon explains why total the body weight of the 5wk-old rabbits was significantly greater in the groups rea red by $\mathrm{V}$-Line does. This may possibly be due to large litter size that reflects good maternal ability and behaviuor [30]. The results oppose those of [31], who reported that Chinchilla dam breed had a significant effect for live litter birth weight than NZW. [25] recorded non-significant differences between NZW and Chinchilla crosses and their reciprocal crosses for the mean body weight at 21 and $35 \mathrm{~d}$ of age. Generally, the growth rate was high during the period between 3 and 5 weeks of age than 0 and 3 weeks which may be attributed to the higher milk production and good mothering ability. Similarly, [32] revealed the same significant effect of the breed (Flemish Giant and Californian White) during 2-3 week among all pre-weaning ages. Different from previous results, [33] recorded nonsignificant differences in average daily gain (ADG) during all pre-weaning periods (1, 2, 3 and 4 week) between two synthetic rabbit genetic groups (APAU Fawn and APAU Black). Crossbred progeny that resulted from $V$-Line as female showed higher estimates tha $\mathrm{n}$ its reciprocal crosses for total and a verage wei ght gain without a significant effect during the period from birth till 21 day. Similar to previous results, [34] recorded a significant effect of crossbreeding among the rabbit breeds and their crosses for the growth rate during the period of 0-2, 2-4 and 0-4 weeks. Also, [32] reported a highly significant effect of crossbreeding on ADGs during 0-1, 1-2 and 3-4 weeks and a significant effect during 2-3 week a mong Flemish Giant, Californian White and their crosses. Whilst, crossbreds recorded significantly higher ADGs at all the pre-weaning ages studied, except at 4 weeks of age. The mortality up to weaning is a reproductive factor that is considered to be an express of individual maternal traits. These results a re pa rallel to findings [22], who found a non-significant breed effect (Rex, NZW and Californian) for born dead, pre-weaning and post-weaning mortalities. controversy to the pres ent results, [19] indicated that Baladi Red recorded a significantly ( $\mathrm{P} \leq 0.05$ ) higher mortality rate of the young than those recorded in NZW. Similarly, [23] revealed that $\mathrm{V}$-Line estimated higher litter mortality between 21 and 28 days than Alex. Furthermore, [17] recorded higher percentage of pre-weaning mortalities in Californian breed than Havana black. Non-significant effect of crossbreedingon mortality rate between purebreds and crossbreds are similar to the results of [27], who showed a non-significant crossbreeding effect on pre-weaning mortality a mong Chinchilla (CH), NZW and Dutch (D) breeds that ranged from $13.69 \%(\mathrm{NZW} \times \mathrm{D})$ to $20.95 \%(\mathrm{D} \times \mathrm{CH})$. Also, [35] detected a non-significant difference between studied genetic groups (Pannon KaxPannon Ka, Pannon Whitex Pannnon Ka and Pannnon LargexPannon Ka) for mortality \%. On the other hand, [36] found a highly significant crossbreeding effect on pre-weaning mortality in which Baladi Red showed higher pre-weaning mortality \% values when used as sire than when used as dam with Simenwar, French Giant Papillion and Chinchilla Giganta bucks. The heavier is the market weight, the higher is the kilograms of rabbit marketed and the higher is the profit [37]. The previous findings are matched with the result of [22], who showed significant differences among breeds (NZW, Californian and Rex) for total return (TR) and total cost (TC). The Rex showed the highest TR (35.35 L.E/ rabbit) but the lowest net profit (NP) (10.40 LE / rabbit). NZW recorded superiority for net profit (11.15 LE / rabbit). Whilst, there was no significant difference among NZW, Californian and Rex for net profit which contradicts the result of the current experiment. Regarding crossbreeding effect, the current study clarified a significant effect of purebred, crossbreds and reciprocal crossbred on economic efficiency measures are matched with results of [38] who demons trated that there were significant differences a mong purebred, crossbred and reciprocal crossbred of Californian, NZW and Gabali on economic efficiency mea sures in which $\mathrm{NZW} \times$ Gabali showed the lowest total cost and the highest net profit and net profit/total cost ratio. On the other hand, Gabali showed the highest return value and NZW showed lowest net profit/total cost ratio.

\section{Conclusion}

It could be recommended that using V-Line (as a doe) with Baladi Black. Purebred V-line (VơxVP) showed 
Improvement in the litter traits and economic efficiency compared with the other genetic groups.

\section{Conflict of interest statement}

The authors declare that there is no any conflict of interest in the current research work

\section{Animal ethics committee permission}

The current res earch work was executed according to standards of Research Ethics Committee, Faculty of Veterinary Medicine, Mansoura University.

\section{Authors' contributions}

Shima a A.Sa kr conducted the experiment and a nalytical procedures; Hend A.Radwan helped with writing the manus cript; Adel I.EL-Desoky performed s tatistical a nalysis; Ragab A. Darwish revised the manuscript; Mohamed M. Fouda edited the manuscript.

Table 4. Litter traits (Means $\pm \mathrm{SE}$ ) of various mating groups of rabbit from birth till weaning.

\begin{tabular}{|c|c|c|c|c|c|c|}
\hline \multirow[t]{2}{*}{ productive parameters } & \multicolumn{5}{|c|}{ Treatments groups $\left(0^{x} \times \uparrow\right)$} & \multirow{2}{*}{ P-value } \\
\hline & & $\mathbf{V} \times \mathbf{V}$ & $\mathbf{B} \times \mathbf{V}$ & $\mathbf{V} \times \mathbf{B}$ & $\mathrm{B} \times \mathrm{B}$ & \\
\hline \multirow[t]{3}{*}{ Alive litter Size } & At birth & $7.40 \pm 0.34$ & $7.26 \pm 0.32$ & $7.26 \pm 0.31$ & $7.11 \pm 0.24$ & NS \\
\hline & 21 days & $7.03 \pm 0.31$ & $6.76 \pm 0.28$ & $6.88 \pm 0.26$ & $6.69 \pm 0.26$ & NS \\
\hline & 35 days & $6.74 \pm 0.29$ & $6.53 \pm 0.27$ & $6.30 \pm 1.16$ & $6.30 \pm 1.43$ & NS \\
\hline \multirow{3}{*}{ Alive litter weight (g) } & At birth & $420.00 \pm 15.84^{A}$ & $376.73 \pm 15.52^{B}$ & $349.42 \pm 14.03^{\mathrm{BC}}$ & $330.38 \pm 9.27^{c}$ & $<.0 .0001$ \\
\hline & 21 days & $2276.11 \pm 93.53^{A}$ & $2090.00 \pm 86.04^{\mathrm{AB}}$ & $2074.03 \pm 81.01^{\mathrm{AB}}$ & $1851.92 \pm 73.64^{\text {B }}$ & $<0.01$ \\
\hline & 35 days & $5198.88 \pm 209.5^{A}$ & $4410.30 \pm 244.4^{B}$ & $4058.84 \pm 167.8^{B C}$ & $3606.92 \pm 168.1^{c}$ & $<.0 .0001$ \\
\hline \multirow[t]{3}{*}{ Mean body weight (g) } & At birth & $57.40 \pm 0.82^{\mathrm{A}}$ & $52.30 \pm 0.57^{B}$ & $48.26 \pm 0.62^{c}$ & $46.73 \pm 0.62^{c}$ & $<.0 .0001$ \\
\hline & 21 days & $325.37 \pm 3.11^{\mathrm{A}}$ & $309.61 \pm 3.30^{B}$ & $301.53 \pm 2.88^{C}$ & $276.73 \pm 2.02^{D}$ & $<.0 .0001$ \\
\hline & 35 days & $774.62 \pm 5.03^{\mathrm{A}}$ & $696.92 \pm 6.28^{B}$ & $645.96 \pm 4.90^{c}$ & $565.00 \pm 6.52^{D}$ & $<.0 .0001$ \\
\hline \multirow[t]{3}{*}{ Average litter daily weight gain (g) } & $0-21$ days & $267.96 \pm 2.99^{A}$ & $257.30 \pm 3.20^{B}$ & $253.26 \pm 2.64^{B}$ & $230.00 \pm 1.90^{c}$ & $<.0 .0001$ \\
\hline & 21-35 days & $449.25 \pm 4.61^{\mathrm{A}}$ & $387.30 \pm 4.33^{B}$ & $344.42 \pm 4,25^{c}$ & $288.26 \pm 5.90^{D}$ & $<.0 .0001$ \\
\hline & $0-35$ days & $717.22 \pm 4.89^{A}$ & $644.61 \pm 6.21^{B}$ & $597.69 \pm 4.87^{c}$ & $518.26 \pm 6.66^{D}$ & $<.0 .0001$ \\
\hline \multirow[t]{3}{*}{ Average kit daily weight gain (g) } & $0-21$ days & $12.76 \pm 0.14^{\mathrm{A}}$ & $12.25 \pm 0.15^{B}$ & $12.06 \pm 0.13^{B}$ & $10.95 \pm 0.09^{c}$ & $<.0 .0001$ \\
\hline & 21-35 days & $29.95 \pm 0.31^{\mathrm{A}}$ & $25.82 \pm 0.29^{B}$ & $22.96 \pm 0.28^{C}$ & $19.21 \pm 0.29^{D}$ & $<.0 .0001$ \\
\hline & $0-35$ days & $20.49 \pm 0.14^{\mathrm{A}}$ & $18.42 \pm 0.17^{\mathrm{B}}$ & $17.08 \pm 0.14^{c}$ & $14.81 \pm 0.19^{D}$ & $<.0 .0001$ \\
\hline \multirow[t]{3}{*}{ Mortality rate (\%) } & $0-21$ days & $4.41 \pm 1.48$ & $6.14 \pm 1.73$ & $4.44 \pm 1.44$ & $6.10 \pm 1.87$ & NS \\
\hline & 21-35 days & $3.55 \pm 1.24$ & $2.80 \pm 1.24$ & $7.52 \pm 1.93$ & $5.36 \pm 1.79$ & NS \\
\hline & $0-35$ days & $7.96 \pm 1.98$ & $8.94 \pm 2.20$ & $11.96 \pm 2.32$ & $11.45 \pm 2.52$ & NS \\
\hline
\end{tabular}

${ }^{A, B}$ Means within the same row carrying different capital superscripts are significantly different at $P<0.01$ and $P<0.0001$.

NS: Not significant.

Table 5. Economic efficiency of various mating groups in growing rabbit diets (Mean \pm SE).

\begin{tabular}{|c|c|c|c|c|c|}
\hline \multirow{2}{*}{ Parameters } & \multicolumn{5}{|c|}{ Treatment groups $\left(0^{\pi} \times \%\right)$} \\
\hline & $\mathbf{V} \times \mathbf{V}$ & $\mathbf{B} \times \mathbf{V}$ & $\mathbf{V} \times \mathbf{B}$ & $\mathrm{B} \times \mathrm{B}$ & $p$-value \\
\hline Total feed intake (Kg/Rabbits) & $6.004 \pm 0.38$ & $5.986 \pm 0.25$ & $6.109 \pm 0.36$ & $6.641 \pm 0.07$ & NS \\
\hline Total weight gain (Kg/ Rabbits) & $1.801 \pm 0.01^{\mathrm{A}}$ & $1.647 \pm 0.02^{\mathrm{B}}$ & $1.628 \pm 0.01^{B}$ & $1.435 \pm 0.02^{C}$ & $<0.0001$ \\
\hline Price/kg feed (L.E) & 4.50 & 4.50 & 4.50 & 4.50 & \\
\hline Total feed cost / Rabbits (L.E) & $27.02 \pm 1.70$ & $26.94 \pm 1.11$ & $27.49 \pm 1.61$ & $29.88 \pm 0.31$ & NS \\
\hline Price/kg live body weight (L.E) & 35 & 35 & 35 & 35 & \\
\hline Total return/ Rabbits (L.E) & $62.92 \pm 0.48^{\mathrm{A}}$ & $57.58 \pm 0.94^{B}$ & $56.46 \pm 0.51^{B}$ & $50.24 \pm 0.61^{c}$ & $<0.0001$ \\
\hline Net return (L.E) & $35.90 \pm 1.42^{\mathrm{A}}$ & $30.64 \pm 1.40^{\mathrm{B}}$ & $28.96 \pm 1.69^{B}$ & $20.36 \pm 0.42^{C}$ & $<0.0001$ \\
\hline Economic efficiency (EE) & $1.390 \pm 0.16^{\mathrm{A}}$ & $1.161 \pm 0.10^{\mathrm{AB}}$ & $1.104 \pm 0.15^{\mathrm{AB}}$ & $0.681 \pm 0.01^{B}$ & $<0.004$ \\
\hline
\end{tabular}

${ }^{A}, \mathrm{~B}$ Means within the same row carrying different capital superscripts are significantly different at $\mathrm{P}<0.0001$ and $\mathrm{P}<0.004$ NS: Not significant. 


\section{REFRENCES}

[1] Herbert U. Unending seeds and waters of animal life. 12th Inaugural lecture series of Michael Okpara University of Agriculture. Umudike, Nigeria 2011 November 9;p 1-41.

[2] Moustafa H. El-Raffa A. Shebl M.K. El-Delebshany A. and El-Sayed N. Genetic evaluation of some economic traits in a maternal line of rabbits. Egyp Poul Sci 2014; 34, 85-98. https://doi.org/10.21608/epsj.2014.5308

[3] Lazzaroni C. Biagini D. Redaelli V. and Luzi F. Technical Note: Year, season, and parity effect on weaning performance of the Carmagnola Grey Rabbit breed. World Rabbit Sci 2012 ;20, 57-60. https://doi.org/10.4995/wrs.2012.1031

[4] Lebas F., Coudert, P., Rouvier, R. and De Rochambeau, H. The Rabbit: husbandry, health, and production, FAO of the United Nations Rome 1997; 21.

[5] Piles M, Rafel O, Ramon J. and Gómez E. Crossbreeding parameters of some productive traits in meat rabbits. World Rabbit Sci 2004; 12, 139-148. https://doi.org/10.4995/wrs.2004.575

[6] Hassanien H. and Baiomy A. Effect of breed and parity on growth performance, litter size, litter weight, conception rate and semen characteristics of medium size rabbits in hot climates. Egypt Poult Sci 2011; 31-45.

[7] El-Deghady A.S. Genetic evaluation for some productive traits in rabbits, Ph. D. Thesis, Faculty of Agriculture, Banha University, Egypt. 2005.

[8] Abdel-Hamid T.M. Crossbreeding parameters for growth traits in a complete three breeds diallel cross design of rabbits in Egypt. J Adv Vet Anim Res 2015;2, 120-127. https://doi.org/10.5455/javar.2015.b60

[9] Council NR. Nutrients requirements of rabbits. 8th Ed. National Academy of Science, Washington, DC, USA. 1994.

[10] Maertens L. Feeding systems for intensive production. In: Nutrition of the rabbit, CABI 2010; pp 253-266. https://doi.org/10.1079/9781845936693.0253

[11] Szendrő K. Effect of genotype and management systems on performance, economics and societal perceptions in rabbit meat production, Kaposvári Egyetem 2014.

[12] SAS. Statistical Analysis System, User's Guide. Statistical. Version 7th ed. SAS. Inst. Inc. Cary. N.C. USA 2004.

[13] Duncan D.B. Multiple Range and Multiple F Tests. Biometrics 1955; 11, 1-42. https://doi.org/10.2307/3001478

[14] Oke U.K. and Iheanocho V. Effect of breed and breeding system on reproductive performance of rabbits in a humid tropical environment. Tropi and Subtropl Agroecosystems 2011; 14, 369-373.

[15] Mambiri L. Evaluation Of Performance Of Doe Genetic Groups Of The Domestic Rabbit At The Ngong Farmers Training Center, Kenya, Doctoral dissertation, University of Nairobi 2013.

[16] Apori SO. Hagan JK. and Osei YD. Growth and reproductive performance of two rabbit breeds reared under intensive system in Ghana. Trop Anim Health Prod 2015; 47, 221-225. https://doi.org/10.1007/s11250-014-0714-2

[17] Fadare A. and Fatoba T. Reproductive performance of four breeds of rabbit in the humid tropics. Lives Res Rur Dev 2018; 30.

[18] Olowofeso O. Adejuwon A. Ademokoya V. and Durosaro S. Breeding and productive performance of three breeds of rabbit in South-West Nigeria. GJSFR 2012; 12, 34-38.

[19] Khalil H. Kishk W. Essa O. and Awad M. Evaluation of productive and physiological performance of Baladi Red compared to New Zealand White rabbits under the same managerial conditions. Egyptian J Anim Prod 2014; 51, 200-209.

[20] Rajapandi S. Ramanathan N. Pourouchottamane R. Thiruvenkadan A.K., Kumar V.R.S. Pankaj P.K. and RajendiranA.S. Analysis of reproductive traits of broiler rabbits reared in sub-temperate climate of Kodai hills, Tamil Nadu, India Veterinary World 2015; 8, 1045-1050. https://doi.org/10.14202/vetworld.2015.1045-1050
[21] Argente M. Blasco A.Ortega J. Haley C. and Visscher P. Analyses for the presence of a major gene affecting uterine capacity in unilaterally ovariectomized rabbits. Genetics 2003; 163, 1061-1068.

[22] Abdel-Hamid T.M. and Omar M.A. Economic Evaluation for Some Productive Traits in Rabbit Breeds within Egypt. In: Proceedings of the 6th Scientific Conference of Animal Wealth Research in the Middle East and North Africa 2013; pp 27-30.

[23] El-Sabrout K. and Shebl M.K. Effect of Line and Season on Productive Performance of Rabbits. International Journal of Animal Biology 2015; 1, 182-186.

[24] Ashour A. Badwi Y.K. and El-Karim R.E.A. Evaluating performance of three rabbit genotypes under egyptian conditions. J Agric Res Kafr ElSheikh Univ 2016; 42, 115-128. https://doi.org/10.21608/jsas.2016.2877

[25] Egena S S A. Akpa G N. Alemede I C. and Aremu A. Genotype, gestation length, season, parity and sex effects on growth traits of two rabbit breeds and their crosses. Biotehnol Anim Husb 2014; 30, 717729. https://doi.org/10.2298/BAH1404717E

[26] Akinsola O. Nwagu B. Orunmuyi M. Iyeghe-Erakpotobor G. Abanikannda O. Eze E. Shoyombo A. Okuda E. and Louis U. Factors influencing litter traits and body weight at pre-weaning ages among temperate rabbit breeds in the tropical conditions of Nigeria. Sci J Microbiol 2014; 3, 14-18.

[27] Nwakpu P. Ogbu C. and Ugwu S. Hetrosis of Early Growth Performance in Three Breeds of Rabbits (Oryctolagus cuniculus). Int J Agric Innov Res 2015; 3, 1793-1799.

[28] Lukefahr S. Hohenboken W.D. Cheeke P.R. and Patton, N.M. Genetic effects on maternal performance and litter pre-weaning and postweaning traits in rabbits. Anim Sci J 1984; 38, 293-300. https://doi.org/10.1017/S0003356100002300

[29] Ajayi F.O. Ologbose F.I. and Esenowo E.S. Pre-Weaning and Post Weaning Growth Performance of Rabbits: Influence of Genotype and Litter Size in a Humid Tropical Environment. Int J Agric and For 2018; 8, 63-69.

[30] Abdel-Hamid T.M. genetic studies on milk production traits and reproductive efficiency in rabbits.Thesis. Faculty of Veterinary., Medicine, Zagazige University., Egypt. 2010.

[31] Egena S. Akpa G. Alemede I. and Aremu A. Genetic and Non-genetic factors affecting litter size and birth weight of rabbit in Minna, Niger State, Nigeria. j Anim Prod Adv 2013; 14.

[32] Lavanya R. Mahender M. Rajanna N. and Gnanaprakash M. Productive performance of broiler rabbits. Indian J Anim Res 2017; 51, 391-394. https://doi.org/10.18805/ijar.9635

[33] Kunnath S. Durgam S. Manthani G. and Amaravadhi S. Study on Preweaning Growth Performance of Broiler Rabbit Breeds. International Journal of Livestock Research 2018; 8, 234-240. https://doi.org/10.5455/ij|r.20171205103612

[34] Rojan P. Bindu K. and Raja T. Effect of genetic groups on pre-weaning body weights and growth rates of rabbits maintained under organized farm conditions. Vet Res 2012; 5, 68-69.

[35] Szendrő K. Szendrő Z.S. Gerencsér Z.S. Radnai I. Horn P. and Matics Z.S. Comparison of productive and carcass traits and economic value of lines selected for different criteria, slaughtered at similar weights. World Rabbit Sci 2016; 24, 15-23. https://doi.org/10.4995/wrs.2016.3684

[36] Abdel-Azeem A. Abdel-Azim A. Darwish, A and Omar E. Litter traits in four pure breeds of rabbits and their crosses under prevailing environmental conditions of Egypt. In: Proc.: 5th International Conference on Rabbit Production in Hot Climate 2007; pp 4-7.

[37] Zeferino C. Komiyama C. Fernandes S. Sartori J.R. Teixeira P. and Moura A.S.A.M.T. Carcass and meat quality traits of rabbits under heat stress. Animal 2013; 7, 518-523. https://doi.org/10.1017/S1751731112001838

[38] Ali M. and El-Tarabany M. Economic and productive comparsion among three rabbit breeds and their crosses under egyptian conditions. SCVMJ 2013; XVIII, 45-58. 